\title{
A Comparative Study of Gender Differences in Refusal Strategies from English Majors*
}

\author{
Qiaoying Wang \\ School of Foreign Languages, Guizhou University of Engineering Science, Bijie, Guizhou, China
}

\begin{abstract}
Based on Geoffrey Leech's politeness principle (1975), Brown and Levinson's face saving and face threatening theory (1987), this paper is a comparative study of the gender differences in the refusal strategies employed by the English majors. The DCT (Discourse Completing Test) from Tanck Sharyl (2004) is modified in this study. The results of this study show that both male and female students of the English majors use the refusal strategies in a speech act. The differences of refusal strategies between male and female lie in the direct refusal and the indirect refusal. Most of the female students tend to use an indirect refusal politeness strategy to save the others' face in the communication, avoiding the face threatening, while most of the male students seem to use direct refusal. The achievements of this study make some contribution to the relevant study and provide some indications to English teaching and learning in China. It is of some significance to improve the English pragmatic competence of English majors.
\end{abstract}

Index Terms —English refusal strategies, gender differences, politeness, English majors

\section{INTRODUCTION}

Kasper and Rose (2001) stated that in social communication, speakers employ a variety of speech acts to achieve their communicative goals, such as apologies, requests, complaints, and refusals. English refusal speech act belongs to the research field of English pragmatics. English pragmatics mainly studies whether English learners can properly carry out speech acts in verbal communicative activities to achieve the purpose of communication. English speech act theory, the cooperative principle, the politeness principle and the face saving theory are the main contents of English pragmatic theories, all of which are regarded as the important theories that the relevant researches are based on.

\section{A. Speech Act Theory}

In the early 1950s, the British philosopher John Austin first put forward the speech act theory in his lecture on the topic of How to Do Things with Words in Harvard University. Austin (1965) said that speech actisthat saying something is doing something. The speech act happens when the speakers produce two types of sentences: performatives and constatives. In his opinion, the descriptive sentences belong to the constatives while the performatives refer to the uttering of these sentences or the doing of an action. Soon, however, he found it worthless to distinguish performatives and constatives because saying anything at any time can be regarded as the doing of something or an act of speech. Then he developed his theory into another more effective speech act theory. According to Austin's theory (1965), there may be three kinds of speech acts which the speakers carry out: the locutionary act, the illocutionary act and the perlocutionary act. He defined the meaning of locutionary act as the actual uttering of a sentence with a particular meaning which refers to the speech act in which the speaker use words, phrases, and clauses to express his ideas. He analyzed the literal meaning of the speech act at the linguistic level, such as syntax, vocabulary, phonology and etc. He explained that in illocutionary act when a locutionary act happens, the speakers' purposes and intentions have been expressed by producing some units of language or verbal expressions with certain meanings, and the perlocutionary act brings the consequences or the effects on the hearers after locutionary act. On the basis of Austin's speech act theory, American philosopher John Searle (1969) inherited and developed Austin's speech act theory and created his own theory, including a series of rules and norms. He explained that the speech act refers to physical act, perlocutionary act, and illocutionary act and the rules of the language must be involved in the speech act. The speaker expresses his purpose or intentions by using different forms of language. According to Searle, speech acts fall into five categories: assertives, directives, commissives, expressives, and declaratives. His theory holds that the utterances that can be made to perform the same act may vary in their syntactic forms.

\section{B. The Cooperative Principle}

Paul Grice, American philosopher and linguist, made great contributions to the cooperative principle. Grice (1975) pointed that the interlocutors have to obey a general conversational principle in a talk to reach the successful communication, which is called the cooperative principle. He proposed four conversational maxims based on his

\footnotetext{
* This present study is supported by Humanities and Social Sciences Research Project from Department of Education, Guizhou Province and Guizhou University of Engineering Science. Project No. is $13 Z \mathrm{ZC} 068$.
} 
cooperative principle. The four conversational maxims are the Maxim of Quantity, the Maxim of Quality, the Maxim of Relation and the Maxim of Manner. He observed that sometimes the speaker violates some of these principles consciously to achieve a certain aim or purpose.

\section{The Politeness Principle}

On the basis of Grice's cooperative principle, Geoffrey Leech (1983) put forward the principle of discourse politeness, including six Maxims of politeness: Tact Maxim, Generosity Maxim, Approbatory Maxim, Modesty Maxim, Agreement Maxim and Sympathy Maxim. Tact Maxim means reducing cost and making more benefit to the hearer involved in the communication. Generosity Maxim refers to minimizing the speaker's own benefits to achieve the politeness. In Approbatory Maxim, the hearer is offered more praise and less offensiveness. Modesty Maxim denotes that the speaker minimizes his own praise to maximize the hearer's praise. Agreement Maxim conveys that the speaker intends to narrow the differences between the hearers and the speaker himself. Sympathy Maxim connotes the reduction of the antipathy to each other. He believed that in verbal communication, in order to achieve politeness, people use different pragmatic strategies in speech acts.

\section{The Face Theory}

Erving Goffman (1955) proposed face work. He claimed that people need to use polite language to avoid embarrassment in verbal communication and hurt their own and the others' image and face. Continuous studies done by Brown and Levinson on face contribute much to the face theory. Brown and Levinson (1987) defined the face as the public self-image recognized by others in the society and they divided the face into negative face and positive face. The negative face means the freedom of action and freedom from imposition. The positive face means the self-image appreciated and approved of by the others. Further, Brown and Levinson advanced face-threatening act (FTA), which refers to an utterance or action which threatens a person's public self-image or face. FTA threats the hearer's face by imposing some negative speech acts, such as requests, orders, anger, disagreement, criticism, accusations, insults, contradiction, boasts, confessions, admission of responsibility, ask for forgiveness and so on. They pointed out that the strategies of avoiding face damage are the most polite strategies in communicative activities. Brown and Levinson summed up four politeness strategies: bald on record, negative politeness, positive politeness, and off-record-indirect strategy. They provided more appropriate strategies to minimize or avoid face-threaten to offend the hearer, such as appellation, membership, exaggeration, joke, offer, promise, being optimistic, reciprocity, reason, hedge, apologize, seeking agreement, avoiding disagreement, asserting common ground, giving deference and incurring a debt, etc.

\section{E. The Refusal Strategy}

Brown \& Levinson (1987) regarded the speech act of refusal in communication as the direct act to conduct the face threatening, which can break down the communication. Fraser (1990) and Smith (1998) found in their studies that refusals are influenced by some social factors such as gender, age, education background, power, and social distance. If a speaker does not employ the appropriate refusal strategy, the hearer's face will be hurt and their relationship may be damaged, so that the communication fails and it is very important for the interlocutors to adopt the different refusal strategies to reduce the negative influence of the refusal speech act. Beebe et.al. (1990) studied the refusal strategies and divided the strategies of refusal into three categories: direct refusal, indirect refusal and adjuncts. Direct refusal means that the speaker makes direct refusal to the other's request, invitation, offer, and suggestion, etc., including performative and non- performative statements. For example, the speaker uses the performative words like 'refuse', 'decline', and 'reject' to refuse the other interlocutors or some non-performative statements and negative willingness or ability, such as 'No' or 'I can't or 'No, I don't like it' and so on. Indirect refusal strategy is an indirect way to do the refusal. There are a variety of strategies to conduct the indirect refusal. The refusal strategies involved in this paper are based on the taxonomy proposed by Beebe et al (1990, pp.72-73) (See Appendix 2).

\section{F. Research Background}

Based on the achievements above, a great many academic researches on the refusal strategies have been conducted at home and abroad. The studies performed by Blum-Kulka and House (1989) House \& Kasper (1987), Ellis, R. (1992), Garcia, C. (1993), Hassall, T. J. (2001), Jeremy F. Jones, Adrefiza (2017) and Lana Kreishan (2018) focused on the polite speech acts of apology and request, and the other scholars, such as Murphy \& Neu (1996), Tanck, Sharyl (2004), studied the complaints and refusals. Allami, et.al.(2017) examined the different levels in employing the strategies of speech acts related to request, apology, and refusal. In recent years, foreign scholars have begun to combine the study of the refusal strategies in their own languages, cultures and English learning. Hatime Çiftç (2016) dealt with a contrastive analysis on the use of politeness strategies in refusal of speech acts between Turkish and English native speakers. Paraskevi-Lukeriya L Iliadi andTatiana V Larina (2017) explored refusal speech acts and the use of refusal strategies in English and Russian. Tuncer, Hülya (2016), Tuncer Hülya and Turhan, Burcu (2019) found in their research that the refusal strategies used in social activities by pre-service English teachers are influenced by gender difference and the social status in Turkey.

There are also many researchers in China who studied the speech acts and refusal strategies. Ma Yuelan (2000) conducted a research on refusal strategies from the written discourses and concluded 11 kinds of refusal strategies that 
can be used in the situations of Chinese and English language learning. Gong Ping (2005) proposed a format of refusal strategy $(\mathrm{C} \chi \rightarrow \mathrm{R} \gamma)$, which holds that the corresponding switching between the refusal strategy parameter $\gamma$ and the cognitive parameter $\mathrm{x}$ can help the speakers to conduct a more appropriate refusal speech act. Zhu Xiaoning (2010) focused on how college students use politeness strategies in English communications. Pei Lixia (2010) investigated difference of the refusal strategies between English majors, non-English majors and native English speakers. Guo Yinling (2012) made a contrastive analysis on the similarities and differences in the use of strategies in English and Chinese refusal speech acts from the perspective of pragmatics. Her research shows that the participants in communicative activities with different social status will adopt different refusal strategies. Yuan Lan and Liu Ping (2018) fulfilled the research based on the research of the samples of the spontaneous dialogues and conversations selected from (ESCCL) and found that Chinese English learners tend to employ the indirect refusal strategies when conducting communications. Wang (2018) analyzed the polite strategies in the media simultaneous interpreting to avoid the face threatening based on Goffman's face work (Goffman, 1955) and Brown \& Levinson's face saving theory (Brown \& Levinson, 1987).

Because of the lack of real English language learning environment, it is difficult for learners who learn English as a foreign language to master authentic English completely. Even if students with good academic performance communicate with people who use English as their native language, there will be communication obstacles, which is not necessarily due to the students' poor spoken English. The politeness of speech act is related to the weak pragmatic competence of English language, so it is very important to improve students' pragmatic communicative competence. Since fewer studies have been conducted on refusals, especially, in Chinese cultural context, this paper aims to investigate the refusal strategies the Chinese students adopt in certain situations and the differences between Chinese female and male students' refusal strategies. Taking Guizhou University of Engineering Science as an example, this study attempts to make a contrastive study on the gender differences in English refusal strategies employed by female and male students majoring in English when they respond to the different refusal situations on the DCT (Discourse Completion Test) which was designed on the Survey Questionnaire sheet and analyzes whether the gender differences of English majors will affect the use of politeness in English refusal speech acts. The study attempts to explore the following research questions:

1. What refusal strategies do the Chinese students employ in this study?

2. Is there any difference of the refusal strategies employment between male and female students? If there is, what is the difference?

3. Do the refusal strategies that the female students/male students employ make face threatening?

\section{METHOD}

\section{A. Participants}

Fifty female students involved in this study were randomly selected from the junior college students majoring in English in Guizhou University of Engineering Science. Because there are few male students majoring in English in China, 14 out of 23 male English majors involved in this study come from the other colleges in Guizhou Province. The ages of the students are from 18 to 22 years old and most of them are Han, 9 girls and 4 boys are Yi, Hui, Buyi and Miao ethnic groups. Most of the students have learned English for 8 or 13 years. The number of students who graduated from rural schools and urban schools is almost the same; half of the students learned English in rural middle schools in China and another half in urban schools. Female students are Group 1 (Gr. 1) and male students are Group 2 (Gr.2).

\section{B. Material}

The participants will be provided with a Survey Questionnaire Sheet comprised of personal information survey and a Discourse Completion Test (DCT). As for personal information, the participants are asked to provide basic information (age, gender, course of study, and specific information including length of formal English learning). The Discourse Completion Test (DCT) is made up of ten prompts. It is likely that the response to the speech act of request seems to conduct the face threatening so that most of the prompts of situations except the invitation of Situation 10 in this study are involved in this study. All prompts are the specific speech acts that are the focus of the study -refusals. Each prompt is likely to occur in a university setting and all of them are listed in random order. Among the ten prompts, five of them are DCT form, the other 5 are multiple choice, considering offering some hints or help to the students with weak English to finish the DCT easily. The DCT format is modified from Sharyl Tanck's (2004, p.20-22) by the researcher. (See Appendix 1)

\section{Procedures}

The participants were asked to write their personal information first anonymously. Then they were required to complete the DCT by writing what their oral response would be to each situation of the refusal speech act. They were encouraged to respond quickly, and not to carefully analyze their responses, to write their responses as soon as possible. Then the responses from all the participants were collected as data for analysis. The number of responses from female students (Gr.1) and the male students (Gr. 2) is calculated in percentage. 


\section{Data Analysis}

Components of each speech act from the collected data will be analyzed. Speech act set of a refusal could consist of several individual speech act components such as a direct refuse (No, I can't), an apology (I'm sorry I am afraid I can't), a pity (Pity!; It's pity!), an explanation or reason (I have lent it to the others.), a suggestion (What about ...?) and so on. The number of the male students or female students who employ the refusal strategies was calculated for the percentage, and make a comparative analysis of the gender difference in refusal strategies. The refusal strategies employed by the participants will be also analyzed from the face threatening perspective. The refusal strategies were analyzed based on the taxonomy adapted from Beebe et. al. (1990, pp.72-73) (See Appendix 2).

\section{RESUlTS AND DisCUSSION}

\section{A. Comparison of Employed Refusal Strategies}

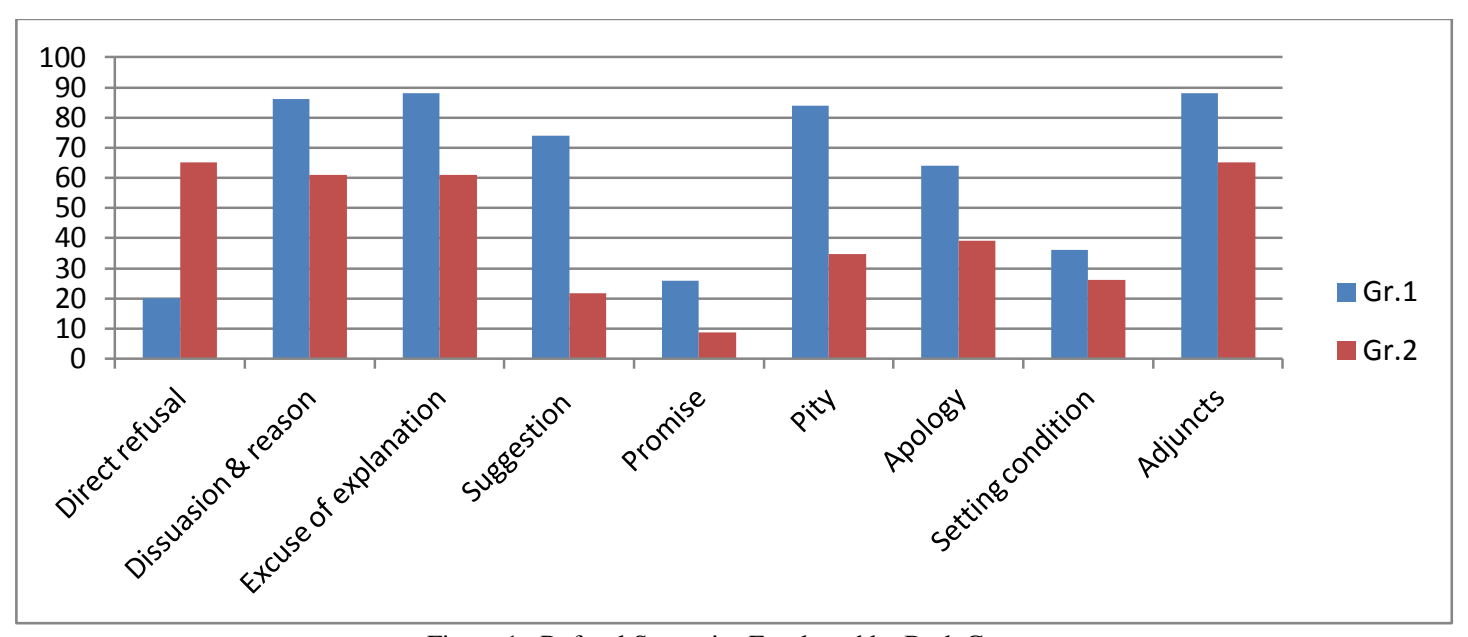

Figure 1. Refusal Strategies Employed by Both Groups

Fig. 1 shows the strategies that the male students and female students employ in their responses to the DCT related to the refusal politeness strategies. It attempts to provide the answer to the first research question: "What refusal strategies do the Chinese students employ in this study?"

It can be seen from Fig.1 that both female (Gr. 1) and male students (Gr. 2) adopt the refusal strategies in English refusal speech act, and the main strategies are direct refusal, indirect refusal and adjuncts. In this study, the strategies the students of both groups adopted the three kinds of refusal strategies. And the indirect refusal strategies involved in this study are dissuasion and reason, excuse of explanation, suggestion, promise, pity, apology, setting condition and adjuncts. From this figure, it is clear that dissuasion and reason, excuse of explanation and adjuncts seem to be the most favorite refusal strategies favored by both male students and female students. More than half of the responses from both groups to the Situation 1 concern the dissuasion and reason of refusal strategy. The students attempt to persuade their parents to give up their plan or request that they ask his or her child to do a job he or she does not like by providing a lot of reasons. Excuse of explanation is another strategy popular with the male students and female students. It may be due to the reason that when a speaker has to voice, he or she would say a lie rather than tell the true feeling or views (Brown and Levinson, 1987). Due to the reason that the students are taught to practice using them fluently since they began to learn English, it seems to be reasonable for most of the participants to employ adjuncts (I'd love to...; Pity! Thanks!) , Fig. 1 attempts to provide the answer to the first research question. On the contrary, the refusal strategies of promise and setting condition are avoided by the male students and female students. It seems to be possible that few of the students utilize the two strategies because the failure to keep a promise influence one's credit or fame according to the Modesty Maxim (Leech, 1983) and the reason why only a few of the students use the strategy of setting condition may be the complexity of the subjunctive mood to make the students difficult to understand its usage and function.

\section{B. Comparison of Gender Difference in Refusal Politeness Strategies}


TABLE I.

THE COMPARISON OF GENDER DIFFERENCES IN REFUSAL POLITENESS STRATEGIES (GROUP 1-MEMALE GROUP2 -MALE)

\begin{tabular}{|l|l|l|l|l|}
\hline Category of Strategy & Group 1 & $\%$ & Group2 & $\%$ \\
\hline Direct refusal & 10 & 20.0 & 15 & 65.2 \\
\hline Dissuasion and reason & 43 & 86.0 & 14 & 60.9 \\
\hline Excuse of explanation & 44 & 88.0 & 14 & 60.9 \\
\hline Suggestion & 37 & 74.0 & 5 & 21.7 \\
\hline Promise & 13 & 26.0 & 2 & 8.7 \\
\hline Pity & 42 & 84.0 & 8 & 34.8 \\
\hline Apology & 32 & 64.0 & 9 & 39.1 \\
\hline Setting condition & 18 & 36.0 & 6 & 26.1 \\
\hline Adjuncts & 44 & 88.0 & 15 & 65.2 \\
\hline
\end{tabular}

*The percentages in brackets show the number of respondents in a given group

Tab.1 shows the comparison of gender differences in refusal politeness strategies based on the number of the respondents in the given groups. It is clear that the great differences between the male students and the female student in refusal strategies. Tab.1 aims to satisfy the second research question: Is there any difference of the refusal strategies employment between male and female students? If there is, what is the difference?

It is demonstrated in Tab.1 that the indirect refusal strategy used by female students is significantly higher than that used by the male students, which indicates that the female students tend to use much more polite refusal strategies than the male students. In the employment of the indirect refusal strategies, there are also significant gender differences in the use of suggestion ( $74 \%$ for female and $21.7 \%$ for male), promise ( $26 \%$ for female and $8.7 \%$ for male), pity ( $84 \%$ for female and $34.8 \%$ for male), and apology (64\% for female and 39.1\% for male). As for the other refusal strategy such as dissuasion and reason, excuse of explanation, setting condition and adjuncts, the gender differences do not enlarge the gap between the male students and female students.

Tab.1 displays that there are significant gender differences in direct refusal and indirect refusal strategies. Only 20 percent of female students refuse directly, while 65 percent of male students used direct refusal strategies, which is significantly higher than girls. This may be resulted from the man's supremacy in China because in Chinese traditional culture, a man has the authority or the power to make a decision directly (Cao, 2004). For Situation 1, the most of the male students say "no" directly to his parents, classmates and friends. When he was asked by his parents to accept the work they asked him to do, male students directly replied, "No, I don't like the job. I'm not interested. They use such non-performative statements to express directly the negative willingness to make a refusal. However, the female students use persuasion and reasoning strategies to persuade their parents: "Mum, I see you just care for me, but I have grown up, I have to learn to be independent. So I would like to make a decision by myself. Anyway, thanks, Mum ". The female students use address (Mum) and adjunctions such as 'Thank you or thanks' to narrow the distance from the hearer. As for the suggestion strategy, the number of the male students is quite lower than that of the female who accounts for $74 \%$ of the female participants, while the males only for $21.7 \%$. Compared with the male students, the female students are more likely to refuse her roommate who asks her to go to the cafeteria to bring her food by promising to fetch the food, for example: "Ok, but I will go to the dining hall late. If you waited for me, I would fetch some for you. From the Tab.1, a conclusion can be reached that the female students tend to make more polite refusals than the male students. It can be explained from the psychology perspective that the females are very sensitive, gentle, soft, mild, sympathetic and considerate to the other's feelings and behave very carefully not to hurt the others' face (Wu, 2016).

\section{Face Threatening in Refusal Strategies}

According to Brown and Levinson (1987), polite and euphemistic English refusal Strategy in the speech acts is the best way to avoid face threatening. The Face Saving Theory requires that all people who take part in communicative activities are Model Persons, who need to mind their own image and face. Marina Terkourafi (2015) explained that since the speech act of refusal is the most dangerous act to threaten directly the face of those involved in the communication, it is necessary to employ polite refusal semantic formula to reduce and avoid the face threatening to the participants in verbal communication activities to achieve the successful communication. Beebe et.al.(1990) claimed that the direct refusal should be avoided using in communicative activities, because the direct refusal directly uses "No, I can't" to refuse the request, suggestion or invitation from those who participate in the communication, it directly hurt the hearer's face. Therefore, in order not to threaten the face of the hearer, the speakers should try their best to use indirect refusal strategy and adjuncts in a refusal speech act to avoid or reduce the face threatening by expressing regret, providing suggestions, offering explanations and giving reasons, dissuasion and other indirect ways of refusal.

In this study, we can see from Tables 1 and 2 that there are significant gender differences in English refusal strategies. The results of this study indicate that a face threatening occur in refusal speech acts. It is observed in Fig. 1 and Tab.1 that the female students rarely employ direct refusal strategies in communications, while $65 \%$ of the male students use direct refusal strategies. Therefore, the female students utilize appropriate refusal strategies to avoid the face threatening by the strategies of dissuasion and reasoning, explanation, giving reasons and promises and other refusal strategies; saving his/her own face as well as the hearers'. It is supposed that using more than one refusal strategy in one speech act 
reaches effective politeness and avoid the face threatening. For example, in the multiple-choice task, the answer A is the direct refusal, answer B the indirect and answer $\mathrm{C}$ is much more indirect in Situation 7 where answer C contains pity strategy with an excuse or reason to express the speaker's unwillingness to refuse and difficulty in compliance. The answer C seems the most politeness to save the listener's face. The same way can be observed in the other four situations. According to John Searle (1969) and Geoffrey Leech (1983), the different syntactic forms convey the different meanings and different pragmatic strategies achieve politeness in a speech act. Hence, it is suggested by Erving Goffman (1955) and Brown and Levinson (1987) that in refusal speech acts the interlocutors attempt to employ the most euphemistic refusal strategies to avoid face threatening and make politeness to achieve the successful communication.

\section{CONCLUSION}

The results of this study show that both male and female students adopt certain strategies in English refusal speech acts. The polite refusal strategies include direct refusal, indirect refusal and adjuncts. It is obvious that the different gender employs the different refusal strategies. Most of the female students tend to use indirect refusal strategies such as dissuasion and reason, excuse of explanation, suggestion, promise, pity, apology, setting condition and adjuncts while the male students are likely to utilize direct refusal strategy or less indirect refusal. It is the best policy for the interlocutors to attempt to employ the most euphemistic refusal strategies in refusal speech acts to avoid face threatening and make politeness to achieve the successful communication.

To some extent, this study makes a contribution to the domestic research on whether the gender differences of English majors affect the employment of English refusal strategies in the speech acts. There are some teaching implications for English learning and teaching to foster the improvement of the students' pragmatic competence.

\section{APPENDIX. A}

Survey Questionnaire Sheet

The DCT is modified from Sharyl Tanck's (2004, p.20-22)

Thank you for your participation!

Age Gender Grade

The years that you have been learning English

Part I Answer the following questions in English according to the following situations. Please answer them promptly, not spending too much time thinking.

Situation 1. If your parents ask you to apply for the job that you do not like, what do you say to refuse to them?

Situation 2. Your girlfriend/or boyfriend asks you to have a meal together but you are still angry with her/him. What do you say to refuse him/her?

Situation 3. Your roommate asks you to lend him/her your laptop to play computer games a little while but you don't want to lend him/ her. What do you say to refuse him/her?

Situation 4. A classmate asks you to buy some food from the university canteen (学校餐厅) for him/her, if you don't want to do that, what do you say to refuse him/her?

Situation 5. When you spend the weekend or holiday in your home, if your neighbor asks you to take care of her children, what do you say to refuse her/him?

\section{Part II MULTIPLE CHOICE (Choose only one response to each situation.)}

Situation 6: One friend of your brothers' asks you to lend him some money to buy a new mobile phone. You would really prefer not to lend him. What would you say if you want to refuse?
A. No, I can't.
B. Sorry, I'm afraid I can't.

C. What about you asking him (your brother) to borrow some to you?

Situation7: One day, one of your classmates comes to you to borrow your book card to borrow a book from your school. You do not really know him, and you worry that he cannot return the book. What would you say if you want to refuse?
A. No, I can't.
C. Pity! I've lent it to another classmate.
B. Sorry, I'm afraid I can't. 
Situation 8: Your close friend asks you to help with his assignments. You have an important exam coming up. What would you say if you want to refuse?

A. Sorry, I'm afraid I couldn't.

B. I would be happy to help you if I hadn't too hard exam tomorrow.

C. Sorry, I'm really busy these days preparing for my exam.

Situation 9: Your teacher asks you to stay after school to help clean up his office. You really have many other things that you need to do. What would you say if you want to refuse?

A. Sorry, I'm afraid I can't. $\quad$ B. I wish I could.

C. Miss Wang, I'm afraid I can't. I have something important to do during that time.

Situation 10: One day, your friend's teacher (he does not know who you are) is playing basketball on the playground and catches sight of you walking by. He invites you to join him. What would you say if you want to refuse?

A. No, I've no interest.

B. Sorry, I'm afraid I couldn't.

C. I'd love to but I am poor at playing at basketball.

APPENDIX. B

Taxonomy of Refusal Strategy adapted from Beebe et. al. (1990, pp. 72-73):

\section{Direct}

1. Using performative verbs (I refuse)

2. Non performative statement
○ "No"
- Negative willingness/ability (I can't./I won't./I don't think so)

\section{Indirect}

1. Statement of regret (I'm sorry.../I feel terrible...)

2. Wish (I wish I could help you...)

3. Excuse, reason, explanation (My children will be home that night./I have a headache)

4. Statement of alternative

- I can do X instead of Y (I'd rather.../I'd prefer...)

○ Why don't you do X instead of Y (Why don't you ask someone else?)

5. Set condition for future or past acceptance (If you had asked me earlier, I would have...)

6. Promise of future acceptance (I'll do it next time./I promise I'll.../Next time I'll...)

7. Statement of principle (I never do business with friends.)

8. Statement of philosophy (One can't be too careful.)

9. Attempt to dissuade interlocutor

$\circ$ Threat or statement of negative consequences to the requester (I won't be any fun tonight to refuse an invitation)

- Guilt trip (waitress to customers who want to sit a while: I can't make a living off people who just order coffee.)

- Criticize the request/requester (statement of negative feeling or opinion; insult/attack (Who do you think you are?/That's a terrible idea!)

- Request for help, empathy, and assistance by dropping or holding the request

- Let interlocutor off the hook (Don't worry about it./That's okay. / You don't have to.)

- Self-defense (I'm trying my best./I'm doing all I can do.)

10. Acceptance that functions as a refusal

○ Unspecific or indefinite reply

- Lack of enthusiasm

11. Avoidance

○ Nonverbal

- Silence

- Hesitation

- Doing nothing

- Physical departure

o Verbal

- Topic switch

- Joke

- Repetition of part of request (Monday?)

- Postponement (I'll think about it.)

- Hedge (Gee, I don't know./I'm not sure.

\section{Adjuncts to Refusals}

1. Statement of positive opinion/feeling or agreement (That's a good idea.../I'd love to...) 
2. Statement of empathy (I realize you are in a difficult situation.)

3. Pause fillers (uhh/well/oh/uhm)

4. Gratitude/appreciation

\section{ACKNOWLEDGEMENTS}

Thanks must go to all the students involved in this study and the teachers who help the researcher collect the Survey Questionnaire Sheets. This present study is supported by Humanities and Social Sciences Research Project from Department of Education, Guizhou Province and Guizhou University of Engineering Science. Project No. is $13 Z$ C068.

\section{REFERENCES}

[1] Allami, Hamid \& Boustani, Nasim. (2017). Iranian EFL Learners' Awareness of (Im)politeness Strategies in English. Journal of Research In Applied Linguistics, 2017, 1, 89-108.

[2] Austin, J.L. (1965). How to do things with words. Oxford: Oxford University Press.

[3] Beebe, Leslie M., Takahashi, Tomoko \& Robin, Uliss-Weltz. (1990). Pragmatic transfer in ESL refusals In Scarcelle, R. C., Anderson, E. \& Krashen, S. C. ( Eds.). Developing Communicative Competence in a Second Language. New York: Newbury House, 55-73.

[4] Blum-Kulka, Shoshana \& Juliane, House. (1989). Cross-cultural and situational variation in requesting behavior. In Shoshana Blum-Kulka, Juliane House and Gabriele Kasper (Eds).Cross-cultural pragmatics: Requests and apologies. Norwood, NJ: Ablex Publishing, 123-154.

[5] Brown, P. \& Stephen, C. Levinson. (1987). Politeness: Some Universals in Language Use. Cambridge: Cambridge University Press.

[6] Cao Shu-wen. (2004). White Deer's Plain: A Classical Piece of Male Supremacy. Journal of Henan Normal University (Philosophy and Social Sciences Edition), 3, 157-161.

[7] Ellis, R. (1992). Learning to communicate in the classroom: A study of two language learners' requests. Studies in Second Language Acquisition, 14, 1-23.

[8] Erving, Goffman. (1955). On Face-Work. Psychiatry Interpersonal and Biological Processes. 18(3), $213-23$.

[9] Fraser, B. (1990). Perspectives on Politeness. Journal of Pragmatics, 14, 219-236.

[10] Garcia, C. (1993). Making a request and responding to it: A case study of Peruvian Spanish speaker. Journal of Pragmatics, 19: 127-152.

[11] Geoffrey, Leech. (1983). Principles of Pragmatics. London: Longman Group Limited.

[12] Gong Ping. (2005). An analysis of $C X \leq R \gamma$ cognitive model of refusal. M.A. dissertation, Fudan University.

[13] Grice, H. P. (1967). Logic and conversation. Studies in Syntax \& Semantics Speech Acts,38(1):101-136.

[14] Guo Yinling. (2012). A cross-cultural pragmatic contrastive study of refusal speech strategies in English and Chinese. Journal of Guangdong University of Foreign languages and Foreign Trade, 23 (4), 47- 51.

[15] Hassall,T. J. (2001). Modifying requests in a second language. International Review of Applied Linguistics, 39, $259-283$.

[16] Hatime Çiftçi. (2016). Refusal strategies in Turkish and English: a cross-cultural study. ELT Research Journal, 2016,1 , 3-6.

[17] House, J. \& G. Kasper. (1987). Interlanguage pragmatics: Requesting in a foreign language. In W. Lörscher \& R. Schultze (Eds.). Perspectives on language in performance. Festschrift für WernerHüllen. Tübingen: NarrVerlag, 1250-1288.

[18] Jeremy F. Jones \& Adrefiza. (2017). Comparing apologies in Australian English and Bahasa Indonesia: Cultural and gender perspectives. Journal of Politeness Research-Language Behaviour Culture, 13(1), 89-119.

[19] John, Searle R. (1969). Speech Acts. Cambridge: Cambridge University Press.

[20] Kasper, Gabriele \& Kenneth R Rose (Eds.). (2001). Pragmatics in Language Teaching. Cambridge: Cambridge University Press.

[21] Lana Kreishan. (2018). Politeness and Speech acts of Refusal and Complaint among Jordanian Undergraduate Students. International Journal of Applied Linguistics and English Literature, 7(4), 68-76.

[22] Ma Yuelan. (2000). A comparative study on the commonalities of refusal strategies between China and the United States. Journal of Xi'an Institute of Foreign languages, 2, 46-47.

[23] Marina Terkourafi. (2015). The pragmatics of politeness by Geoffrey Leech (review). Language, 91(4), 957-960.

[24] Murphy, B. \& J. Neu. (1996). My grade's too low: The speech act set of complaining. In S.M.Gass \&J. Neu (Eds), Speech acts across cultures: Challenges to communication in a second language. Berlin: Mouton de Gruyter, 191-216.

[25] Paraskevi-Lukeriya L Iliadi \& Tatiana V Larina. (2017). Refusal strategies in english and russian. Rudn Journal of Language Studies, Semiotics and Semantics, 8(3), 531-542.

[26] Pei Lixia. (2010). A survey on refusal of speech act acquisition by English majors: taking non-English majors and native English speakers as reference. Journal of Suzhou Institute of Education, 2, 99-103.

[27] Smith, Frank. (1998). The Book of Learning and Forgetting. New York: Teachers College Press.

[28] Tanck, Sharyl. (2004). Speech act sets of refusal and complaint: A comparison of native and non-native English speakers' production. TESOL Working Papers, 4(2), 1-22.

[29] Tuncer, H. (2016). Refusal strategies used by Turkish university instructors of English. Novitas-ROYAL Research on Youth and Language, 10(1), 71-90.

[30] Tuncer, Hülya \& Turhan, Burcu. (2019). Refusal Strategies of Turkish Pre-Service Teachers of English: A Focus on Gender and Status of the Interlocutor. Journal of Language and Linguistic Studies, 1, 1-19.

[31] Wang Yanqiang. (2018). The Face Work in Media Interpreting. Shanghai Journal of Translation, 6, 44-49.

[32] Wu Sijing. (2016). A Comparative Study of Refusal Strategies: between Chinese Females and English Females. M.A. dissertation, Xian International Studies University.

[33] Yuan Lan \& Liu Ping. (2018). A study on refusal speech Act of English majors based on speech Library: a case study of refusal 
to offer actively. Journal of Xi'an University of Foreign Studies, 26 (4), 62-67.

[34] Zhu Xiaoning. (2010). A study on the Application of Politeness Strategies in College students' English speech acts. Journal of Yangzhou University (higher Education Research Edition), 6, 90- 93.

Qiaoying Wang was born in Bijie of Guizhou, China. She received her M.A. degree in English Language Teaching from De La Salle University, the Philippines in 2005.

She is currently an associate professor in School of Foreign Languages in Guizhou University of Engineering Science, Bijie, Guizhou, China. Several papers have been published these years. They are Needs Analysis on English Majors for Comprehensive English Classroom Teaching Design, Journal of Guizhou University of Engineering Science, Lexical Inferencing Strategies for Dealing with Unknown Words in Reading-A Constrastive Study between Filipino Graduate Students And Chinese Graduate Students, Journal of Language Teaching and Research Vol 2, No. 2, March 2011, Classroom Interaction and Language Output. English Language Teaching Vol.3, No.2, June 2010 and The Effects of Simplified and Elaborated Texts on Second Language Reading Comprehension: an Exploratory Study. VIGO International Journal of Applied Linguistics, No.2, 2005. Her research interests include English language learning \& teaching and English pragmatics. 